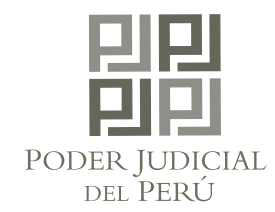

\title{
IV CONGRESO INTERNACIONAL SOBRE JUSTICIA \\ INTERCULTURAL 2012
}

\author{
DECLARACIÓN DE LIMA
}

\section{Los participantes en el IV Congreso sobre Justicia Intercultural realizado del 13 al 15 de diciembre de 2012 en la ciudad de Lima, después de los debates realizados en un ambiente de diálogo intercultural, declaramos lo siguiente:}

Saludamos el esfuerzo de los jueces y de las autoridades indígenas, campesinas y ronderiles de todo el país en pro de la paz social y la justicia intercultural.

Saludamos también la labor de casi seis mil Jueces de Paz quienes logran promover el acceso a la justicia de millones de peruanos en las zonas rurales de nuestro país.

Saludamos las experiencias de coordinación llevadas a cabo en diversas Cortes Superiores, especialmente la labor de las Oficinas Distritales de Apoyo a la Justicia de Paz y las Escuelas de Justicia Intercultural.

Reiteramos nuestro compromiso con el proceso de reflexión y diálogo iniciado en el año 2010 a través de los cuatro Congresos Internacionales sobre Justicia Intercultural e invocamos a las autoridades del Poder Judicial y a las autoridades de la jurisdicción especial a mantener su interés y vocación por la reflexión sobre esta problemática, sustentando sus decisiones en las normas nacionales e internacionales sobre los derechos de los pueblos indígenas.

Invocamos a las autoridades de la jurisdicción ordinaria y la jurisdicción especial a unir esfuerzos para superar las posibles situaciones de conflicto que todavía persisten, manteniendo una permanente comunicación, teniendo siempre como mira el respeto de los derechos fundamentales y un enfoque intercultural, garantizando los derechos lingüísticos. 
Invocamos a las autoridades de la jurisdicción ordinaria y la jurisdicción especial a unir esfuerzos para garantizar los derechos de las mujeres y niños en los casos de violencia familiar.

Invocamos a las Cortes Superiores a desarrollar y fortalecer los mecanismos y criterios de coordinación entre los sistemas de justicia ordinaria y especial.

Recomendamos proseguir el proceso de sistematización de jurisprudencia sobre justicia intercultural y difundir sus resultados.

Recomendamos fortalecer el trabajo de las Escuelas de Justicia Intercultural, como espacios de intercambio de saberes, investigación y capacitación, promoviendo que trabajen en conjunto con las demás instituciones del sistema de justicia estatal, las organizaciones representativas de la jurisdicción especial y los pueblos indígenas. Recomendamos también crearlas en las Cortes Superiores donde todavía no existen.

Recomendamos la creación de una Escuela Nacional de Justicia Intercultural que se dedique a armonizar y potenciar los esfuerzos que desarrollan las Cortes Superiores en investigación y capacitación en justicia intercultural.

Respaldamos al Consejo Ejecutivo del Poder Judicial, en su labor de fortalecimiento de la justicia intercultural, a través de la aprobación e implementación de la Hoja de Ruta de Justicia Intercultural presentada por la Comisión de Trabajo sobre Justicia Indígena y Justicia de Paz.

Invocamos al Congreso de la República la pronta discusión y aprobación del Proyecto de Ley 313/2011-PE sobre coordinación y armonización intercultural de la justicia, presentado en septiembre del 2011 por la Sala Plena de la Corte Suprema de Justicia de la República.

Recomendamos encargar a la Oficina Nacional de Apoyo a la Justicia de Paz la elaboración de un protocolo de relacionamiento entre la jurisdicción especial y la jurisdicción ordinaria, basado en el mencionado proyecto de ley y las conclusiones de los cuatro Congresos Internacionales de Justicia Intercultural.

Invitamos al Ministerio Público y a la Policía Nacional a sumarse a la causa de la justicia intercultural, brindando a sus integrantes la necesaria capacitación en esta materia. 
Invitamos a la Academia de la Magistratura a tomar en cuenta criterios de reflexión intercultural en el proceso de formación de los magistrados y fiscales y al Consejo Nacional de la Magistratura para integrar en sus criterios de evaluación la formación en justicia intercultural.

Invocamos a las Facultades de Derecho de las universidades públicas y privadas y a los colegios de abogados a fomentar la reflexión y la investigación sobre justicia intercultural.

Recomendamos a todos los jueces, jueces de paz y autoridades indígenas, campesinas, nativas y ronderiles profundizar los valiosos esfuerzos para promover la paz social y el acceso efectivo a la justicia para todos los peruanos y peruanas.

Agradecemos el compromiso del Presidente del Poder Judicial, Doctor César San Martín Castro de promover el diálogo entre la jurisdicción ordinaria y la jurisdicción especial y el interés del Doctor Enrique Mendoza Ramírez, Presidente electo del Poder Judicial de proseguir esta valiosa labor, que permitirá garantizar la paz y la justicia social a nivel del país.

Asimismo, agradecemos al Centro de Investigaciones Judiciales -CIJ- en la presidencia del Dr. Vicente Walde Jáuregui, por el impulso que se le viene dando a la justicia intercultural para mejorar la coexistencia pacífica de todas las instituciones comprendidas en este anhelo insoslayable de integración e inclusión social.

Finalmente, saludamos los esfuerzos de nuestra representación en la defensa de los intereses nacionales ante la Corte Internacional de la Haya en donde debe culminar con éxito nuestro reclamo.

Lima, 15 de diciembre de 2012 



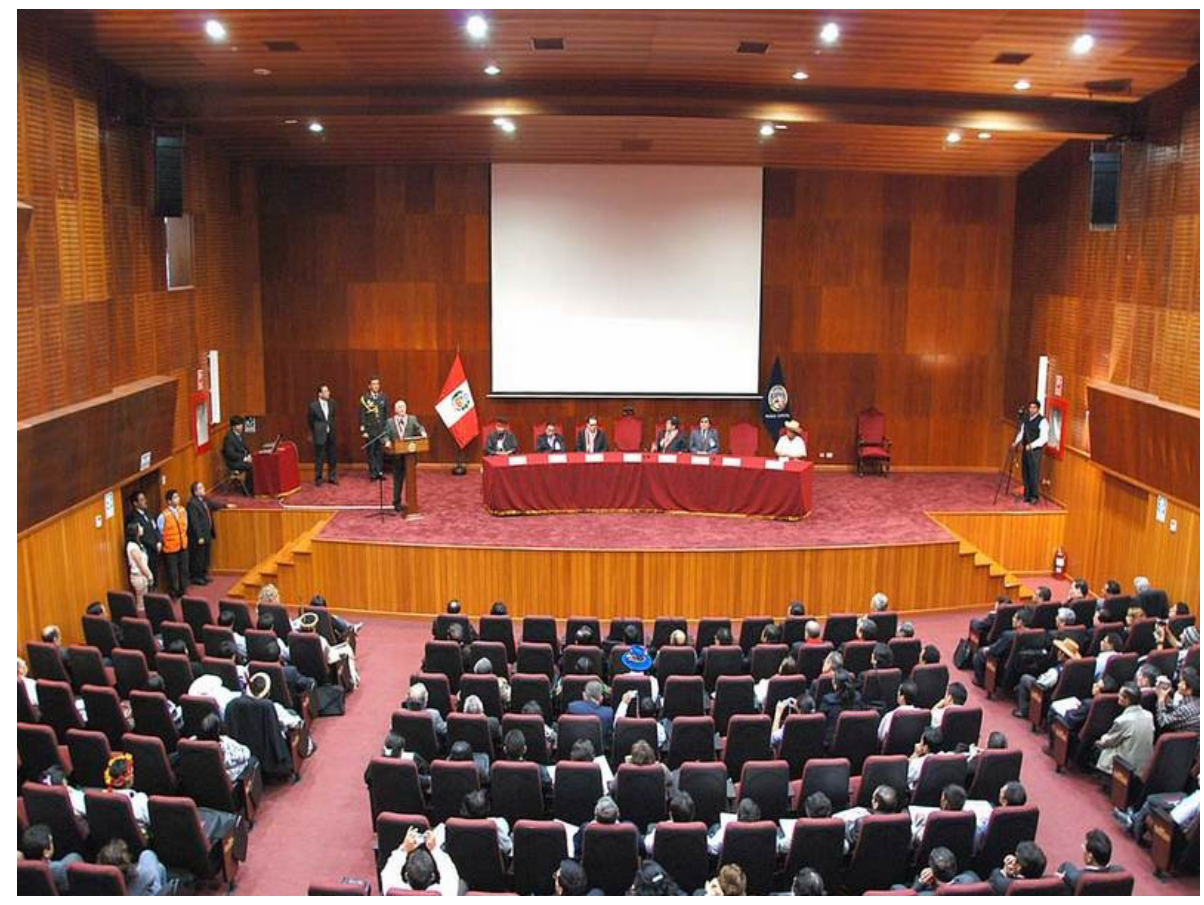

IV Congreso sobre Justicia Intercultural. Lima. 